\title{
PERSPEKTIF HUKUM ISLAM TERHADAP PENCALONAN DIRI DAN KAMPANYE UNTUK JABATAN POLITIK
}

\author{
Muhammad Ashsubli \\ Jurusan Syariah STAIN Bengkalis \\ Jl. Lembaga-Senggoro Bengkalis-Riau \\ e-mail: subli.stain@gmail.com
}

\begin{abstract}
Self candidacy and campaign for particular political position by someone can be accepted in Islamic laws as long as he fulfills two important points. First, he or she possesses capacity, capability, and acceptability to assume positions he or she applying and campaigning for. Second, his or her genuine motivation is to seek. for God's willing and to realize public's own good sake as well instead of striving for his or her own personal goals and medium for for things that are destructive for public needs.
\end{abstract}

Kata kunci: pencalonan diri, kampanye, jabatan politik

\section{PENDAHULUAN}

K ata-kata "Sumber Hukum Islam' Masadir al-Ahkam. Kata-kata tersebut tidak ditemukan dalam kitab-kitab hukum Islam yang ditulis oleh ulamaulama figh dan ushul figh klasik. Untuk menjelaskan arti 'sumber hukum Islam', mereka menggunakan al-adillah alsyariyyah. Penggunaan mashadir alahkam oleh ulama pada masa sekarang ini, tentu yang dimaksudkan adalah searti dengan istilah al-adillah al-syar'iyyah (Fathurrahman Djamil, 1999: 82).

Adapun yang dimaksud Masadir alAhkam adalah dalil-dalil hukum syara' yang diambil (di-istinbath-kan) daripadanya untuk menemukan hukum (Wahbah alZuhaili, t.th.: 401). Sumber hukum dalam Islam, ada yang disepakati (muttafaq) para ulama dan ada yang masih diperselisihkan (mukhtalaf). Adapun sumber hukum Islam yang disepakati jumhur ulama adalah Alquran, Hadis, Ijma' dan Qiyas. Para Ulama juga sepakat dengan urutan dalil- dalil tersebut di atas (Alquran, Sunnah, Ijma' dan Qiyas).

Sedangkan sumber hukum Islam yang masih diperselisihkan di kalangan para ulama selain sumber hukum yang empat di atas adalah istishan, maslahah mursalah, istishab, 'uruf, madzhab as-Shahabi, syar'u man qablana, dan sadd al-dzariyah. Dengan demikian, sumber hukum Islam berjumlah sebelas, empat sumber hukum yang disepakati dan tujuh sumber hukum yang diperselisihkan (Abdul Wahhab al-Khallaf, 1978: 21-22).

Sebagian ulama menyebutkan enam sumber hukum yang masih diperselisihkan itu sebagai dalil hukum bukan sumber hukum, namun yang lainnya menyebutkan sebagai metode ijtihad.

Keempat sumber hukum yang disepakati jumhur ulama yakni Alquran, Sunnah, Ijma' dan Qiyas, landasannya berdasarkan Hadis yang diriwayatkan dari Sahabat Nabi Saw Muadz ibn Jabal ketika diutus ke Yaman.

"Dari Muadz ibn Jabal Ra bahwa Nabi Saw ketika mengutusnya ke Yaman, Nabi 
bertanya: "Bagaimana kamu jika dihadapkan permasalahan hukum? Ia berkata: "Saya berhukum dengan kitab Allah". Nabi berkata: "Jika tidak terdapat dalam kitab Allah"?, ia berkata:"Saya berhukum dengan Sunnah Rasulullah Saw" Nabi berkata: "Jika tidak terdapat dalam Sunnah Rasul Saw."? ia berkata: "Saya akan berijtihad dan tidak berlebih (dalam ijtihad)". Maka Rasul Saw memukul dadanya dan berkata: "Segala puji bagi Allah yang telah memberi petunjuk utusannya (Muadz) dengan apa yang diridai Rasulullah Saw (Al-Mu'jam al-Kabir, t.th.: 96).

Hal yang demikian dilakukan pula oleh Abu Bakar Ra apabila terjadi kepada dirinya perselisihan, pertama ia merujuk kepada kitab Allah, jika ia temui hukumnya maka ia berhukum padanya. Jika tidak ditemui dalam kitab Allah dan ia mengetahui masalah itu dari Rasulullah Saw, ia pun berhukum dengan Sunnah Rasul. Jika ia ragu mendapati dalam Sunnah Rasul Saw, ia kumpulkan para sahabat dan ia lakukan musyawarah. Kemudian ia sepakat dengan pendapat mereka lalu ia berhukum memutus permasalahan (Wahbah al-Zuhaili, t.th.: 402).

Dengan demikian pada prinsipnya kedudukan ijtihad sangat dibutuhkan oleh umat Islam mengingat banyaknya persoalan-persoalan umat yang perlu ditetapkan oleh mujtahid terutama hal-hal yang terkait dengan bidang politik tentang pencalonan dan kampanye untuk jabatan publik.

\section{PENGERTIAN DAN UNSUR-UNSUR IJM ${ }^{\prime}$}

Ijma' dalam pengertian bahasa memiliki dua arti. Pertama, berupaya (tekad) terhadap sesuatu. disebutkan أجمع الأمعال berarti berupaya di atasnya.

Sebagaimana firman Allah Swt:

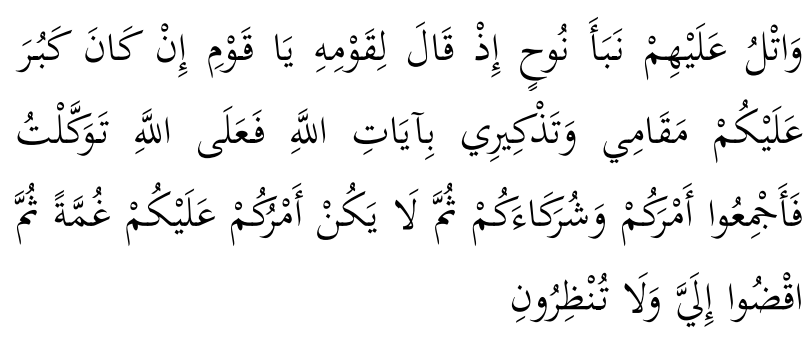

Dan bacakanIah (wahai Muhammad) kepada mereka berita penting (tentang) Nuh di waktu dia berkata kepada kaumnya, "Wahai kaumku! Jika terasa berat bagimu aku tinggal (bersamamu) dan peringatanku (kepadamu) dengan ayat-ayat Allah, maka kepada Allah aku bertawakal. Karena itu bulatkanlah keputusanmu dan kumpulkanlah sekutu-sekutumu (untuk membinasakanku), dan janganlah keputusanmu itu dirahasiakan, kemudian bertindaklah terhadap diriku, dan janganlah kamu tunda lagi. (Q.S. Yunus [10]: 71).

Pengertian kedua, berarti kesepakatan. Perbedaan arti yang pertama dengan yang kedua ini bahwa arti pertama berlaku untuk satu orang dan arti kedua lebih dari satu orang (Wahbah al-Zuhaili, t.th.: 468). Ijma' dalam istilah ahli ushul adalah kesepakatan semua para mujtahid dari kaum muslimin dalam suatu masa setelah wafat Rasul Saw atas hukum syara.

Adapun rukun ijma' dalam definisi di atas adalah adanya kesepakatan para mujtahid kaum muslimin dalam suatu masa atas hukum syara' .

Kesepakatan itu dapat dikelompokan menjadi empat hal:

1. Tidak cukup ijma' dikeluarkan oleh seorang mujtahid apabila keberadaanya hanya seorang (mujtahid) saja di suatu masa. Karena kesepakatan dilakukan lebih dari satu orang, pendapatnya 
disepakati antara satu dengan yang lain.

2. Adanya kesepakatan sesama para mujtahid atas hukum syara' dalam suatu masalah, dengan melihat negeri, jenis, dan kelompok mereka. Andai yang disepakati atas hukum syara' hanya para mujtahid Haramain, para mujtahid Irak saja, Hijaz saja, mujtahid ahlu Sunnah, mujtahid ahli Syiah, maka secara syara' kesepakatan khusus ini tidak disebut ijma'. Karena ijma' tidak terbentuk kecuali dengan kesepakatan umum dari seluruh mujtahid di dunia Islam dalam suatu masa.

Hendaknya kesepakatan mereka dimulai setiap pendapat salah seorang mereka dengan pendapat yang jelas apakah dengan dalam bentuk perkataan, fatwa atau perbuatan.

\section{KEDUDUKAN IJMA' SEBAGAI DALIL HUKUM}

Perbedaan-perbedaan pendapat di kalangan ulama adalah sesuatu yang biasa terjadi termasuk dalam soal ijma' apakah dapat dipandang sebagai dalil syar'i atau tidak.

Pada prinsipnya Jumhur Ulama ushul figh menyatakan bahwa ijma' sebagai upaya para mujtahid dalam menetapkan hukum suatu kasus yang tidak ada hukumnya dalam nash harus mempunyai landasan. Jumhur Ulama berpendapat bahwa kedudukan ijma' menempati salah satu sumber atau dalil hukum sesudah Alquran dan Sunnah (T. M. Hasbi AshSiddieqy, 1980: 25).

Ini berarti bahwa ijma' dapat menetapkan hukum yang mengikat dan wajib dipatuhi umat Islam bila tidak ada ketetapan hukumnya dalam Alquran dan
Sunnah. Untuk menguatkan pendapat ini, Jumhur Ulama mengemukakan beberapa ayat dan Hadis Nabi diantaranya Q.S. anNisa' ayat 115:

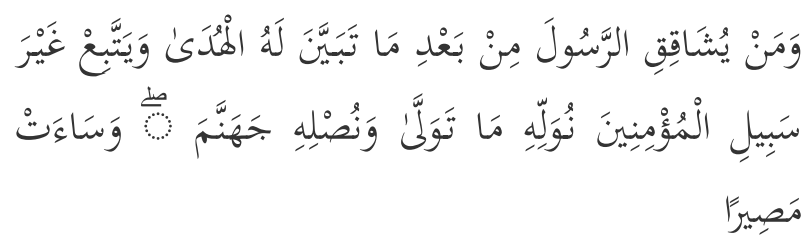

Dan barang siapa yang menentang Rasul sesudah jelas kebenaran baginya dan mengikuti jalan yang bukan jalan orangorang mukmin, maka biarkan ia leluasa terhadap kesesatan yang telah dikuasainya itu dan kami masukkan ia ke neraka jahannam. (Q.S. an-Nisa' [4]: 115)

Zamakhsari mengomentari bahwa ayat ini menunjukkan ijma' mempunyai hujjah yang tidak boleh diperselisihkan sebagaimana Alquran dan Hadis. Sedang Amidy mengatakan bahwa ayat ini merupakan ayat yang amat kuat petunjuknya tentang kehujjahan ijma', di mana Allah Swt mengancam orang yang mengikuti bukan jalan orang mukmin dengan memasukkan ke neraka Jahannam dan tempat yang paling buruk. Jalan orang mukmin diartikan sebagai apa yang disepakati untuk dilakukan oleh orang mukmin. Inilah yang disebut ijma' (Abdullah, Sulaiman, 1995: t.h.).

Begitu juga dalam Alquran surah anNisa (4) ayat 59

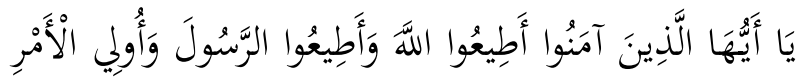

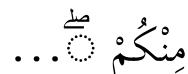

Hai orang-orang beriman, taatilah Allah dan taatilah Rasul-Nya dan ulil amri di antara kamu...(Q.S. an-Nisa [4]: 59)

Perintah mentaati ulil amri sesudah mentaati Allah dan Rasul berarti untuk 
mematuhi ijma', karena ulil amri berarti orang yang mengurus kehidupan umat, baik dalam urusan dunia maupun urusan agama, dalam hal ini adalah ulama. Kepatuhan akan ulama salah satunya adalah bila mereka sepakat tentang sesuatu hukum dan inilah yang disebut ijma' (Djazuli, A., 2007: t.h.).

\section{PENCALONAN DIRI DAN KAMPANYE}

Pencalonan diri berarti proses, cara, dan pembuatan untuk mendapatkan keinginannya. Sedangkan kampanye berarti tindakan atau kegiatan yang dilaksanakan oleh organisasi politik atau calon tertentu yang bersaing memperebutkan kedudukan dalam parlemen dan untuk mendapatkan dukungan massa pemilih dalam suatu pemungutan suara. Sementara jabatan politik berarti pekerjaan (tugas) dalam pemerintahan atau organisasi (Hasan Alwi, 2005: 189).

\section{KONSEP ISLAM TENTANG PENCALONAN DIRIDAN KAMPANYE}

Di dalam hukum Islam, persoalan politik dikenal dengan figh siyasah, memang belum ada pengertian kampanye secara baku. Namun, ada beberapa unsurunsur perilaku di dalam Islam yang mengindikasikan apabila perbuatan tersebut merupakan suatu tindakan yang memiliki makna kampanye, yakni menawarkan diri untuk menjadi pemimpin dan ajakan untuk memilih dirinya sebagai pemimpin (Rapung Samuddin, 2013: 128).

Sedangkan dalam hal ini kampanye ialah sebuah tindakan yang bersifat persuasi. Persuasi yang berarti menghimbau atau perilaku mengajak seseorang dengan cara memberikan alasan serta prospek yang baik untuk meyakinkannya (Antar Venus, 2009: 29).

Di dalam sejarah Islam, istilah kampanye dalam figh siyasah memang belum familiar dan dikenal secara luas. Istilah tersebut telah ada sebelum masa kontemporer ini, di mana telah terbentuk negara-bangsa yang banyak bercorak demokrasi bagi negara yang mayoritas muslim khususnya di Timur Tengah dan Asia Tenggara (Mahomed Ullah Ibn S. Jung, 1990: t.h.).

Pelaksanaan kampanye merupakan salah satu bagian atas terselenggaranya pemilihan umum. Di dalam figh siyasah, istilah pemilihan umum dikenal dengan Intikhabah al-ammah. Intikhabah merupakan jama' muannassalim yang berasal dari kata intikhaba-yantakhibu yang artinya memilih.

Oleh karena itu, dalam hal ini kampanye adalah sebuah sarana sebagai tahap perkenalan diri oleh kandidat yang mencalonkan diri agar khalayak mengetahui keberadaan serta identitas para pihak yang mencalonkan diri tersebut, sehingga dengan demikian umat dapat mengenal dan mampu untuk memilih dan memilah manakah calon kandidat yang pantas untuk menduduki kepemimpinan melalui pelaksanaan pemilihan umum (Hafied Cangara, 2011: 229).

Adapun pihak-pihak yang melaksanakan kegiatan kampanye ini adalah sekelompok tim kampanye yang dibentuk dari partai politik atau gabungan partai politik tertentu. Di dalam figh siyasah, partai politik disebut dengan istilah al-hizb al-siyasi yang dipahami sebagai sebuah organisasi publik yang memperjuangkan nilai-nilai Islam dalam konteks yang berbeda-beda melalui penguasaan struktur kelembagaan pemerintah baik pada level legislatif, maupun eksekutif yang 
diperoleh melalui keikutsertaan dalam pemilihan umum serta melakukan kampanye dengan menjual isu dan program-program yang tidak terlepas dari nilai-nilai ideologis Islam (Ridho alHamdi, 2013: 9).

\section{DASAR HUKUM PENAWARAN DIRI SEBAGAI PEMIMPIN}

Suatu tindakan menawarkan diri untuk menjadi pemimpin, telah dijelaskan dalam firman Allah tentang perkataan Nabi Yusuf As dalam Q.S. Yusuf ayat 55, yakni:

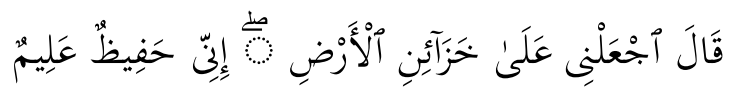

Berkata Yusuf: "Jadikanlah aku bendaharawan negara (Mesir); Sesungguhnya aku adalah orang yang pandai menjaga, lagi berpengetahuan. (Q.S. Yusuf [12]: 55)

Dari ayat di atas, menurut tafsir pendapat ulama al-Allamah al-Alusi (w. $1270 \mathrm{H}$ ), ayat di atas merupakan dalil kebolehan seseorang untuk memuji dirinya dengan sebenar-benarnya jika memang ia tidak dikenal. Demikian pula kebolehan untuk meminta kekuasaan (jabatan) (Fahmi Huwaydi, 1996: 236).

Kekuasaan (jabatan) dapat diminta apabila ada orang yang kafir dan zalim yang juga ingin menguasainya. Oleh karena itu, seseorang yang di dalam dirinya telah terpenuhi syarat-syarat untuk menjadi pemimpin dan sanggup untuk bersikap adil serta menjalankan hukum-hukum syariat, maka calon pemimpin tersebut boleh saja untuk menawarkan diri untuk menjadi pemimpin dan meminta jabatan tersebut (Fahmi Huwaydi, 1996: 236).

Hafidzun 'Alim adalah kekuatan inti Nabi Yusuf As. yang berjuang dengan melibatkan diri ke dalam sistem birokrasi pemerintahan Mesir. Ia berjuang melawan hedonisme dan kekuasaan korup yang menggiring negara pada kehancuran. Seorang ulama yang bernama AlQurthubi (w. $671 \mathrm{H}$ ) menyatakan pula bahwa, ayat tersebut menunjukkan suatu kebolehan untuk seseorang yang meminta jabatan jika dirinya berkompeten. Dijelaskan dalam penafsirannya bahwa, Nabi Yusuf As meminta jabatan karena ia yakin ketika itu tidak ada yang dapat menegakkan keadilan, kebaikan serta hakhak fakir miskin. Hal ini merupakan sebuah kewajiban bagi calon pemimpin untuk menawarkan diri menjadi pemimpin apabila ia memang mampu (Thariq AsSuwaidan, 2005: 30).

Jika seseorang mengetahui bahwa dirinya sanggup menegakkan kebenaran dan keadilan, sedangkan ketika itu tidak ada yang dapat melaksanakannya, maka meminta jabatan menjadi wajib 'ain atasnya. Wajib atasnya memintanya dengan cara mengabarkan tentang perihal diri dan sifat-sifatnya yang layak untuk jabatan tersebut, baik berupa ilmu, kemampuan, syarat-syarat kelayakan untuk menjadi pemimpin, dan lain sebagainya sebagaimana yang dilakukan oleh Nabi Yusuf As.

Kemudian, sifat-sifat seorang calon pemimpin tersebut juga mengandung basthatan fi al-'ilm wa al-jism (keunggulan pada kekuatan ilmu dan fisik). Ibnu Khaldun memiliki gagasan penting mengenai kriteria yang harus dimiliki seorang pemimpin. Pertama, seorang pemimpin itu harus memiliki ilmu pengetahuan; kedua, pemimpin itu harus berlaku adil dalam setiap keputusannya; ketiga, sehat fisik dan jiwanya serta kemampuan lain yang memadai. Hal tersebut dibenarkan oleh Ibnu Qayyim 
bahwa dengan menyempurnakan ilmu, maka kepemimpinan dalam agama akan didapatkan. Kepemimpinan dalam agama adalah kekuasaan yang alatnya adalah ilmu (Ibnu Qayyim Al-Jauziyah, 1999: 76).

Dari beberapa pendapat para ulama di atas, dapat diambil kesimpulan bahwasanya konteks dalam ayat tersebut adalah terdapat kewajiban adanya sifat hafidzun serta alimun terhadap seorang calon pemimpin. Sifat-sifat tersebut menjadi syarat mutlak yang harus ada di dalam diri calon pemimpin sebagaimana yang tersurat di dalam surat Yusuf di atas.

Di dalam syariat Islam, telah disebutkan didalamnya tentang batasanbatasan hak-hak politik individu. Adapun hak-hak politik tersebut diantaranya adalah hak memilih (haqq al-intikhab); hak musyawarah (haqq al-musyawarat); hak pengawasan (haqq al-muraqabat); hak pemecatan (haqq al-'azl); hak pencalonan (haqq al-tarsyih), dan; hak menduduki jabatan (Haqq Tawalliy alWazhaif al-Ammat (Abdul Karim Zaidan, dkk, 2003: 17).

Dalam pembahasan ini akan difokuskan pada hak pencalonan dan hak menduduki jabatan.

\section{Hak Pencalonan (Haqq al-Tarsyih)}

Hak pencalonan ialah tindakan seseorang yang mencalonkan dirinya untuk salah satu jabatan pemerintahan atau fungsi umum lainnya. Di sisi lain, tindak pencalonan diri yang di dalamnya mengandung unsur-unsur permintaan akan suatu jabatan tertentu, tentu tidak diperbolehkan secara syariat, hal demikian sesuai dengan Hadis shahih dari Abdurrahman bin Samurah, Rasulullah Saw berkata kepadanya:

Telah mengabarkan kepada kami Mujahid bin Musa ia berkata; telah menceritakan kepada kami Isma'il dari Yunus dari Al Hasan dari 'Abdurrahman bin Samurah. Telah memberitakan kepada kami Amru bin Ali berkata; telah menceritakan kepada kami Yahya telah menceritakan kepada kami Ibnu Aun dari Al Hasan dari Abdurrahman bin Samurah ia berkata, Rasulullah shallallahu'alaihi wasallam bersabda: Janganlah engkau meminta kekuasaan, karena jika engkau diberi karena permintaan, engkau akan dibiarkan sendiri. Namun jika engkau diberi kekuasaan tidak atas dasar permintaan, maka engkau akan diberi pertolongan dalam menunaikannya. (H.R. Nasa'i) (Lidwa Pustaka, Kitab 9 Imam Hadis, Sunan Nasa'i, Hadis Nomor 5289)

Adapun pencalonan yang memiliki unsur permintaan suatu jabatan oleh individu tidak diperbolehkan, namun boleh hukumnya mencalonkan seseorang untuk orang lain, karena hal tersebut tidak mengandung unsur untuk meminta jabatan (kekuasaan). Akan tetapi mengandung permintaan kepada umat untuk memilih calon yang layak.

\section{Pencalonan di Masa Kini}

Pencalonan diri sendiri tidak diperbolehkan sebagai ketentuan umum, akan tetapi pencalonan diri sendiri diperbolehkan jika dituntut suatu keterpaksaan (keadaan darurat) atau demi kemaslahatan syariat. Di masa kontemporer sekarang ini, umat nampaknya tidak mungkin mengetahui orang-orang yang layak dan cocok untuk mereka pilih menjadi pemimpin. Atas dasar ketidaktahuan umat, maka pencalonan orang yang layak dan memperkenalkan calon tersebut kepada umat dapat membantu umat untuk memilih orang yang paling cocok dan layak untuk menjadi pemimpin demi terealisasinya 
tuntutan-tuntutan yang penting dalam bernegara.

Pencalonan diri ini dibolehkan dengan bersandar pada firman Allah dalam surat Yusuf ayat 55. Di dalam penafsiran ayat tersebut, tidak ada dugaan bahwa Nabi Yusuf As meminta suatu kedudukan karena ketamakannya. Melainkan hal tersebut dilakukan untuk menjadikannya sebagai sarana dalam merealisir tujuan-tujuan yang diridai Allah.

\section{Kampanye Pencalonan}

Apabila pada masa kontemporer ini dalam praktiknya pencalonan boleh dilakukan karena dalam keadaan darurat. Maka bagi orang yang mencalonkan dirinya tidak diperbolehkan untuk melakukan apa yang disebut sebagai kampanye pemilihan yang dilakukan dengan memuji-muji dirinya sendiri dan merendahkan calon-calon yang lain. Namun, seseorang calon boleh memperkenalkan dirinya kepada para pemilih dan menjelaskan gagasan dan langkah-langkah kebijaksanaan kerjanya. Hanya sebatas itu saja yang diperbolehkan oleh calon yang mencalonkan diri.

\section{Hak Menduduki Jabatan (Haqq Tawalliy al-Wazhaif al-'Ammat)}

Menurut syariat Islam, memegang suatu jabatan-jabatan umum bukanlah hak bagi individu, melainkan kewajiban atasnya dari negara. Jabatan-jabatan umum di dalam negara bukanlah hak individu atas negara, karena jika itu merupakan suatu hak, maka permintaan atas suatu jabatan atau kekuasaan tidaklah menjadi sebab atas terhalangnya seseorang untuk meminta jabatan (Komonitas Arab, http://komonitasarab.blogdetik. com, diakses pada tanggal 7 Juli 2015).

Pengisian suatu kedudukan jabatan merupakan kewajiban atas negara. Oleh sebab itu, pemerintahan baik kepala negara dan seluruh pejabatnya harus menyeleksi orang yang paling cocok dan paling layak bagi setiap pekerjaan pemerintahan. Tidak boleh berbuat nepotisme dengan memandang kekerabatan, persahabatan atau golongan dari manapun yang tidak ada hubungannya dengan kelayakan seseorang untuk memegang suatu jabatan.

Para penguasa yang telah ada hendaknya mengangkat para pejabat dari orang-orang yang terbaik (al-ashlah). Nabi bersabda yang artinya,

Barang siapa memegang satu urusan kaum muslimin (maksudnya menjadi penguasa) kemudian ia mengangkat seseorang menjadi pejabat padahal ia mengetahui ada orang lain yang lebih baik bagi (kemaslahatan) kaum muslimin, maka sungguh ia telah mengkhianati Allah dan Rasul-Nya (Ibnu Taimiyah, terj., Rofi' Munawwar 1995: 4).

Apabila kepala negara atau para pejabat lainnya tidak menemukan orang yang tepat untuk sesuatu jabatan tertentu, dalam keadaan ini mereka harus memilih orang yang lebih representatif. Representatif disini memiliki arti yakni orang yang paling tepat dari yang ada untuk setiap jabatan pemerintahan. Dan juga, dalam proses penyeleksian ini, kepala negara dan pejabat lainnya harus mengetahui tentang standar kelayakan alquwwah (kekuatan) dan al-amanah (kepercayaan).

Hal ini didasarkan pada firman Allah dalam surat al-Qashash ayat 26, yakni: 


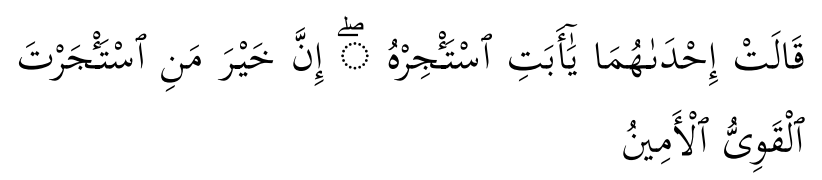

Sesungguhnya orang yang paling baik yang kamu ambil untuk bekerja (pada kita) ialah orang yang kuat lagi dapat dipercaya" (Q.S. Al-Qashash [28]: 26)

Al-Quwwah ialah kemampuan dan kelayakan dalam melaksanakan suatu tugas jabatan. Sedangkan amanah, merupakan perilaku yang dititikberatkan pada proses pengelolaan perihal jabatan atau fungsi dari suatu jabatan yang sesuai dengan syariat Islam dengan niat hanya bertaqwa kepada Allah dan bukan berdasar pada ketakutan kepada manusia dan mengharap pamrih dari mereka (Abdul Karim Zaidan, 1984: 50).

Di masa kini, kaidah dan standar ketepatan harus ditetapkan dan dilaksanakan. Apabila tidak memungkinkan untuk melakukan penyeleksian secara langsung terhadap orang-orang yang akan menduduki jabatan tersebut, maka harus ada penetapan tentang peraturanperaturan yang memuat syarat-syarat untuk memegang suatu jabatan serta batas minimal kelayakan. Kepada seseorang yang berminat untuk memangku jabatan tersebut, diperkenankan untuk mengajukan surat permohonan yang kemudian dilakukan pemeriksaan atas permohonan mereka dan semua hal yang memberi petunjukan atas kelayakan dan kepercayaan mereka.

Dari prosedur di atas, apabila tim penyeleksi dan pemeriksa menemukan seseorang yang layak dan memenuhi syarat, tim penyeleksi harus menunjukkannya secara terbuka dan terang-terangan. Hal ini dikarenakan agar terhindar dari nepotisme dan menghindari juga adanya ketidakadilan. Karena, sesungguhnya kekuasaan yang berada di tangan kepala negara dan seluruh pejabat pemerintahan adalah amanat. Allah akan meridai mereka jika ia melimpahkan jabatanjabatan kenegaraan umum kepada orangorang yang tepat sesuai dengan pedoman syariat dan tidak melimpahkannya kepada kerabat yang paling dekat serta menjauhi orang yang layak dan cocok. Karena tindakan tersebut merupakan pengkhianatan yang dapat menghancurkan amanat.

Sebagaimana termaktub pada sabda Rasulullah Saw:

Jika amanat telah disia-siakan, tunggu saja kehancuran terjadi." Ada seorang sahabat bertanya; 'bagaimana maksud amanat disia-siakan? 'Nabi menjawab; "Jika urusan diserahkan bukan kepada ahlinya, maka tunggulah kehancuran itu.' (H.R. Bukhari).

Di dalam pelaksanaan kampanye sendiri, pasangan calon kandidat yang mencalonkan diri diharuskan untuk menyampaikan visi dan misi serta program kenegaraan yang akan dijalankan. Dalam hal ini, umat atau khalayak masyarakat sangat perlu untuk memperoleh informasi atas pasangan calon kandidat yang mencalonkan diri tersebut, dan kampanyelah yang dapat dijadikan sebagai sarana berkomunikasi politik dan pendidikan masyarakat. Dengan tidak adanya pelaksanaan kampanye sebagai ajang memperkenalkan pasangan calon dan pendidikan politik masyarakat, hal ini dikhawatirkan akan membahayakan umat sendiri. Sebab, khalayak masyarakat tidak mengenal dan mengetahui siapakah yang akan menjadi pemimpin mereka.

Dan juga masyarakat tidak memiliki suatu pertimbangan dasar dalam memilih calon pemimpin mereka melalui pemilihan 
umum. Oleh karena itu, kaidah fikih yang dapat dipakai disini ialah: kebijakan seorang pemimpin atas rakyat harus berdasarkan kemaslahatan (Abdul Haq, 2006: 75-76).

Para pemimpin, abdi negara, pegawai sipil atau militer, hakim, dan lain sebagainya, pada hakikatnya adalah merupakan representasi suara rakyat yang mereka pimpin. Para pemimpin tidaklah lebih dari pelayan masyarakat yang harus mengabdikan dan mendedikasikan kepemimpinannya untuk kemaslahatan rakyat. Para pemimpin hanyalah wakil akan pemenuhan hak-hak umat, sehingga mereka wajib menjalankan roda pemerintahan (tabdir) dengan baik.

Dengan demikian, sangat diperlukan bagi umat untuk mengetahui dan mengenal calon pemimpin yang akan mereka pilih. Karena pemimpin merupakan wakil rakyat yang akan berkuasa di roda pemerintahan. Oleh karena itu, kampanye merupakan sesuatu yang layak dilakukan sebelum adanya pemilihan umum, guna memperkenalkannya kepada khalayak masyarakat dan demi kemaslahatan masyarakat agar tidak salah memilih calon pemimpin (Muhammad Alim, 2010: 192).

Dalam hal ini, Pemilihan Umum merupakan sesuatu yang diundangundangkan dan wajib hukumnya untuk melaksanakannya demi berjalannya roda pemerintahan. Apabila hendak melakukan suatu perbuatan yang hukumnya wajib, maka berbagai upaya dalam melaksanakan kewajiban tersebut hukumnya adalah wajib, termasuk dalam hal ini adalah kampanye. Sesuai dengan kaidah yang berbunyi: apabila suatu perbuatan bergantung pada sesuatu yang lain, maka sesuatu yang lain itu pun wajib.

\section{PENUTUP}

Berdasarkan hasil penjelasan di atas dapat ditarik kesimpulan bahwa pencalonan dan kampanye untuk meraih jabatan politik tertentu dapat dibenarkan menurut hukum Islam bagi seseorang yang dalam dirinya terdapat dua hal. Pertama memiliki kapasitas, kapabilitas, dan akseptabilitas yang memadai untuk mengemban jabatan yang ia mencalonkan dan mengkampanyekan dirinya untuk menggapainya. Kedua, motivasi utamanya tentu semata-mata untuk mencari keridhaan Allah dan demi merealisasikan kemaslahatan publik, bukan untuk menggapai kepentingan pribadi dan atau bukan sarana untuk melakukan hal-hal yang bersifat destruktif bagi kepentingan publik.

\section{DAFTAR KEPUSTAKAAN}

Abdullah, Sulaiman, 1995, Sumber Hukum Islam Permasalahan dan Fleksibilitasnya, Jakarta: Sinar Grafika

Zaidan, Abdul Karim. 1984. Masalah Kenegaraan dalam Pandangan Islam, Terj. Abdul Aziz dalam "Al-Fardu wa Al-Daulah fi Al-Syari'ah AlIslamiyyah", Jakarta: yayasan AlAmin.

Haq, Abdul, Mubarok, Ahmad dkk, 2006. Formulasi Nalar Figh: Telaah Kaidah Figh Konseptual, Surabaya: Khalista.

Venus, Antar. 2009. Manajemen Kampanye: Panduan Teoritis dan Praktis dalam Mengefektifkan Kampanye Komunikasi, Bandung: Simbiosa Rekatama Media.

Djazuli, A. 2007. Kaidah-kaidah Fikih: Kaidah-kaidah Hukum Islam Dalam 
Menyelesaikan Masalah-masalah yang Praktis, Jakarta: Kencana.

Djamil, Fathurrahman. 1999. Filsafat Hukum Islam, Ciputat: Logos Wacana Ilmu.

Huwaydi, Fahmi. Demokrasi, Oposisi, dan Masyarakat Madani, Terj. M. Abd. Ghofar dalam "al-Islam wa alDimuqratiyah", Bandung: Mizan.

Alwi, Hasan. 2005. Kamus Besar Bahasa Indonesia, Jakarta: Balai Pustaka, cet. ke-3

Cangara, Hafied. 2011. Komunikasi Politik: Konsep, Teori dan Strategi, Jakarta: Rajawali Pers.

Lidwa Pustaka, Kitab 9 Imam Hadis, Sunan Nasa'i, Hadis Nomor 5289.

Taimiyah, Ibnu. 1995. Etika Politik Islam, Terj. Rofi' Munawwar dalam "Siyasah Syar'iyah", Surabaya: Risalah Gusti.

Ash-Siddieqy, T. M. Hasbi. 1980. Sejarah dan Pengantar Ilmu Hadis, Jakarta: Bulan Bintang.

Samuddin, Rapung. 2013. Fiqih Demokrasi: Menguak Kekeliruan Pandangan Haramnya Umat Terlibat Pemilu dan Politik, Jakarta: GOZIAN Press.

Jung, Mahomed Ullah Ibn S. 1990. The
Administration of Justice In Islam: An Introduction to The Muslim Conception of The State, New Delhi: Kitab Bhavan.

Alim, Muhammad. 2010. Asas-Asas Negara Hukum Modern dalam Islam (Kajian Komprehensif Islam dan Ketatanegaraan), Yogyakarta: LKiS.

Al-Hamdi, Ridho. 2013. Partai Politik Islam: Teori dan Praktik di Indonesia (Yogyakarta: Graha Ilmu.

As-Suwaidan, Thariq. 2005. Melahirkan Pemimpin Masa Depan, Terj. Faishal Umar, Jakarta: Gema Insani.

Al-Jauziyah, Ibnu Qayyim. 1999. Buah Ilmu, Jakarta: Pustaka Azzam.

Zaidan, Abdul Karim dkk. 2003. Pemilu dan Partai Politik dalam Perspektif Syariah, Terj. Arif Ramdhani dalam "Syar'iyyah al-Intikhabah", Bandung. PT. Syaamil Media.

Wahbah al-Zuhaili, Ushul Fiqh al-Islami, hal 401.

Komunitas Arab, 2015. Hak dan Kewajiban warga negara dalam Islam, (online), http://komunitasarab.blogdetik.com/hak- dan kewajibanwarganegara-dalam islam, diakses pada 7 Juli 2015. 